\title{
Germination, Carbohydrate Composition and Vigor of Cryopreserved Caesalpinia echinata Seeds
}

\author{
Rafael Fonsêca Zanotti ${ }^{1}$, Ludymila Brandão Motta ${ }^{1}$, Juliano Bragatto ${ }^{2}$, Carlos Alberto \\ Labate $^{2}$, Antonieta Nassif Salomão ${ }^{3}$, Wagner A. Vendrame ${ }^{4}$ and Geraldo Rogerio Faustini \\ Cuzzuol $^{\text {* }}$ \\ ${ }^{l}$ Departamento de Ciências Biológicas; Universidade Federal do Espírito Santo; Vitória - ES - Brasil. ${ }^{2}$ Laboratório \\ Max Feffer de Genética de Plantas; Departamento de Genética; "Escola Superior de Agricultura Luiz de Queiroz"; \\ Universidade de São Paulo; Piracicaba - SP - Brasil. ${ }^{3}$ Empresa Brasileira de Pesquisa Agropecuária; EMBRAPA- \\ CENARGEN; Brasília - DF- Brasil. ${ }^{4}$ Tropical Research and Education Center; IFAS - University of Florida; \\ Homestead - FL - USA
}

\begin{abstract}
The present study investigated the germination and vigor of Caesalpinia echinata (Brazilwood) seeds stored at negative temperatures. Recently harvested seeds were cryopreserved at $-18^{\circ}$ or $-196^{\circ} \mathrm{C}$ and periodically evaluated for germination, seed vigor and carbohydrate composition. The temperatures did not influence the germination percentages or vigor. The germination percentage decreased from $88 \%$ in recently harvested seeds to $60 \%$ after 730 days of storage. The different temperature and storage times tested did not affect the vigor seed germination as indicated by the measures of plant growth and survival. The different temperatures used did not cause changes in the carbohydrate composition. The tegument cell walls were rich in lignin, arabinose and xylose. The cytoplasm of the cotyledons and embryos had high levels of glucose, fructose, and sucrose. The cryopreservation technique here presented was effective in the conservation of Brazilwood seeds for the medium term.
\end{abstract}

Key words: Brazilwood, carbohydrate, conservation, germination, seed bank, storage

\section{INTRODUCTION}

Caesalpinia echinata Lam (Brazilwood) is a symbolic tree native to Brazil currently used in the manufacture of quality string musical instruments. The intensive harvesting and uncontrolled extraction of the tree for dye production during the colonization of Brazil reduced the native populations in the Brazilian rainforest and the species has been declared endangered (Barbedo et al. 2002). Furthermore, its irregular fruiting and the loss of germination potential of the seeds only a few weeks after dehiscence (Barbedo et al. 2002) contribute to hinder the recovery of native populations.

After dehiscence, the seeds lose their ability to germinate in about 30 days at room temperature $\left(\sim 25^{\circ} \mathrm{C}\right)$ (Hellmann et al. 2006). Under normal conditions, Brazilwood seed have low tolerance to water loss, and the reduction in their germination potential is associated with the degradation of soluble carbohydrates (Garcia et al. 2006), necessary for cellular respiration in the early stages of germination (Sharma et al. 2005). However, when the seeds are exposed to low temperatures, the carbohydrate content remains unchanged. The concentration of soluble

*Author for correspondence: gcuzuol@gmail.com 
carbohydrates in $C$. echinata seeds remained unchanged after 18 months of storage at low temperatures $\left(6^{\circ} \mathrm{C}\right)$ and was higher than the concentrations seen in the seeds maintained at room temperature (Barbedo et al. 2002).

The stability of energy-rich biomolecules at low temperatures suggests the involvement of soluble carbohydrates in maintaining cryopreserved seed viability (Salomão 2002). Sucrose and raffinose oligosaccharide families have been associated with the membrane stability in the orthodox seeds that are resistant to desiccation (Nkang 2002). Furthermore, there are indications that, in addition to sucrose, glucose and fructose, the cyclitol carbohydrates are closely related to the protective mechanisms of the membranes and organic molecules in Brazilwood seeds (Borges et al. 2006).

In general, the loss of germination potential with the storage time is associated with the deterioration of soluble carbohydrates, particularly the raffinose family oligosaccharides accumulated during the seed maturation (Sharma et al. 2007). These compounds are more abundant in the hypocotyl/roots than in the cotyledons of $C$. echinata (Hellmann et al. 2008), and are not found in the seed tegument of species of the Fabaceae family (Piotrowicz-Cieslak 2005).

The main soluble carbohydrates in $C$. echinata seeds are sucrose, glucose, fructose, myo-inositol and traces of raffinose and stachyose, totaling about $10 \%$ of the dry weight of the seed (Garcia et al. 2006; Hellmann et al. 2008). Ciceritol, galactopinitol A, galacto-pinitol B and sucrose represent the largest reserves of soluble carbohydrates (Borges et al. 2006). Hellmann et al. (2008) found that starch was most abundant carbohydrate reserve, representing $30-40 \%$ of the seed dry weight, followed by the proteins $(8-12 \%)$ and lipids (20\%). However, these authors did not examine the composition of soluble carbohydrates in the cytoplasm or the structural carbohydrates in the teguments and cotyledons of the seeds of $C$. echinata, especially after storage under extreme negative temperatures.

Seed conservation at low temperatures can be accomplished through cryopreservation in liquid nitrogen $\left(-196{ }^{\circ} \mathrm{C}\right)$. Under these extreme conditions, deterioration of biological material does not occur due to the essentially complete shutdown of cellular metabolism. Seed moisture content is a decisive factor in the process of cryopreservation because the formation of ice crystals at low temperatures can cause cell damage (Carneiro and Cal-Vidal 1998, 2000). The change from liquid to solid amorphous meta-stable ice prevents the formation of large crystals and the rupturing of cell membranes (Salomão 2002).

Hellmann et al. (2006) subjected C. echinata seeds to negative temperatures, and reported the best results at $-18^{\circ} \mathrm{C}$, with $60 \%$ germination after 90 days. Barbedo et al. (2002) managed to extend the seed longevity in the same species to 180 days at $7^{\circ} \mathrm{C}$, although the germination levels did not exceed $34 \%$.

A better knowledge of the biochemical composition and germination capacities of the cryopreserved seeds of tropical trees is essential for the conservation of endangered rainforest species. The present study evaluated the effects of negative temperatures on the composition of soluble and structural carbohydrates, germination, and the longevity and vigor of $C$. echinata seeds.

\section{MATERIALS AND METHODS}

Materials and treatments: Freshly harvested Brazilwood seeds were provided by the Brazilwood Foundation (Pernambuco State, Brazil). The initial water content of the seeds was determined by drying at $105 \pm 3^{\circ} \mathrm{C}$ for $24 \mathrm{~h}$, using four replicates of 15 seeds each. The water content of the test seeds was reduced from 12.5 to $8.7 \%$ in the B.O.D. chambers at $40^{\circ} \mathrm{C}$ for $8 \mathrm{~h}$ (Barbedo et al. 2002), and the seeds were then wrapped in aluminum foil and stored in a freezer $\left(-18^{\circ} \mathrm{C}\right)$ or in liquid nitrogen $\left(-196^{\circ} \mathrm{C}\right)$ for $0,30,90,180,365$ and 730 days.

For the germination tests, four replicates of 25 seeds were incubated in lighted B.O.D. chambers at $25^{\circ} \mathrm{C}$ and constant light in Petri glass dishes (Mello and Barbedo 2007) of $9.0 \mathrm{~cm}$ diameter containing moist filter paper with distilled water for ten days. The filter paper was rewetted daily as required. The seeds stored for 730 days received a $0.2 \%$ Nystatin fungicide treatment to control the contamination.

The un-germinated seeds were not tested for the viability. The mean germination time (MGT) was calculated as Labouriau (1983) $t=\Sigma$ ni.ti $/ \Sigma$ ni, where $\mathrm{t}=$ mean germination time; ni=number of germinated seeds in a time interval; $\mathrm{t}=$ time interval in days. 
The seeds stored at low temperatures were thawed at $22^{\circ} \mathrm{C}$ for $4 \mathrm{~h}$. Preliminary tests showed no significant differences between this method of thawing and thawing in a water bath that kept the seeds at $45^{\circ} \mathrm{C}$ for 3 minutes. The slow-thaw was selected in this work due to its practicality. The germination was evaluated daily, and germinated seeds were scored as those having primary roots at least $8 \mathrm{~mm}$ long.

After germination, the seed initial growth was evaluated by transferring the germinating seeds to plastic tubes $(500 \mathrm{~mL})$ containing soil and sand (1:1) under natural temperatures $\left(25^{\circ} \mathrm{C} \pm 3\right)$ and photoperiods $(12 \mathrm{~h} \pm 1)$ in a greenhouse with $50 \%$ shade and average temperatures of $28^{\circ}$ to $20^{\circ} \mathrm{C}$ in the summer and winter, respectively. Ten days after the transfer, plant survival percentage was calculated following the criteria of Barbedo et al. (2002) and Hellmann et al. (2006). The morphology of the plants produced by the seeds stored for 365 days and 730 days at -18 and $196^{\circ} \mathrm{C}$ was also evaluated. The seedlings were grown in the plastic tubes under the same growth conditions described above.

After 30 days, 10 seedlings from each storage temperature and time were transferred to the plastic pots (3L) containing soil and sand (1:1), and analyses for early growth were performed after 150 days of cultivation (June 2006 to November 2008). The growth parameters evaluated were: leaf, stem, and root dry weight, hypocotyl and internode length, number of leaves and nodes, and root dry weight to shoot dry weight ration (after drying these structures in an oven at $60^{\circ} \mathrm{C}$ for 5 days to a constant weight).

\section{Extraction and determination of soluble carbohydrate content}

Cotyledon + embryo $(\mathrm{C}+\mathrm{E})$ and tegument tissues were separated, dried and ground using a microwiley mill. The milled material was separated using 60 mesh screens according to established methods for chemical analysis (ASTM E 1758-01 2001). The soluble carbohydrates (inositol, sorbitol, mannitol, fucose, arabinose, galactose, glucose, sucrose and fructose) were extracted three times using an $80 \%(\mathrm{v} / \mathrm{v})$ ethanol solution at $60^{\circ} \mathrm{C}$. The alcohol supernatants were combined and evaporated using a "speedvac" vacuum system (Eppendorf), and the pellet was re-suspended with $1 \mathrm{~mL}$ of ultrapure water. The soluble sugars were determined using HPAE-PAD (High Performance Anion Exchange - Pulsed Amperometric detection) in an ICS-2500 chromatograph (Dionex (R), containing a CarboPac PA-1 (4 x 250mm) column with an isocratic run (stream $1 \mathrm{~mL} \mathrm{~min}^{-1}$ ) of $4 \mathrm{mM}$ sodium hydroxide $(\mathrm{NaOH})$.

\section{Determination of cell wall carbohydrates}

To determine the chemical composition of the cell wall carbohydrates of the cotyledons + embryo $(\mathrm{C}+\mathrm{E})$ and tegument, a portion of the milled and sieved material was transferred to a Soxhlet extraction platform (ASTM E 1690-01 2001). The extractions were performed in three steps: 1 ) with a mixture of toluene:ethanol (2:1) for $6 \mathrm{~h}$, followed by; 2) $99 \%$ ethanol extraction for $6 \mathrm{~h}$; 3) with boiling water for $1 \mathrm{~h}$. The hydrolysis of the cell walls was performed in $72 \% \mathrm{H}_{2} \mathrm{SO}_{4}$ (ASTM E 1757-01 2001). After the hydrolysis, carbohydrate quantification (fucose, arabinose, galactose, glucose, xylose and mannose) was performed by HPAE-PAD using the same methodology as described above for the determination of soluble carbohydrates. Insoluble and soluble lignin were determined by the gravimetric analysis and spectrophotometry, respectively, according to ASTM E 1721-01 (2001).

\section{Statistical analyses}

Data was analyzed using the analysis of variance (ANOVA) at a 5\% significance level, with means separated by the Tukey's and paired-t tests, when necessary, using the Sigma Stat 3.1 statistical software.

\section{RESULTS}

The germination percentage of $C$. echinata seeds stored at either -18 or $-196^{\circ} \mathrm{C}$ did not differ with the different storage times (Fig. 1A). However, differences between the two temperatures tested and freshly harvested seeds (time 0 ) were significant. While the germination of the seeds cryopreserved at $196^{\circ} \mathrm{C}$ declined by only $12 \%$ after 30 days of storage, this decline was $34 \%$ for the seeds under $-18^{\circ} \mathrm{C}$. The freshly harvested seeds (time 0) showed 88\% germination. After 730 days of storage, the germination percentages were 56 and $64 \%$ for the seeds kept at -196 and $-18^{\circ} \mathrm{C}$, respectively, representing a loss of germination viability of $24-32 \%$ as compared to freshlyharvested seeds ( $88 \%$ germination).

The mean germination time (MGT) ranged from 2.5 to 3.3 days, with no significant differences observed among the temperatures and the different 

different temperatures.

storage periods tested (Fig. 1B). The MGT of 3.3 day at 365 days was attributed to the germinating seeds. The application of Nystatin fungicide $(0.2$ $\%$ solution) during the germination tests at 730 days inhibited pathogen activity and reduced the average germination time to 2.5 days, with no significant differences observed between the

The survival percentage of seedlings produced by the seeds cryopreserved at -18 and $-196^{\circ} \mathrm{C}$ under different storage periods is shown in Fig. 1B. The survival percentage of seedlings produced from the freshly harvested seeds was $80 \%$, while the survival of seedlings obtained from cryopreserved seeds ranged from 50 to $85 \%$. The survival of seedlings grown from seeds stored at negative temperatures for 180 and 365 days had the lowest
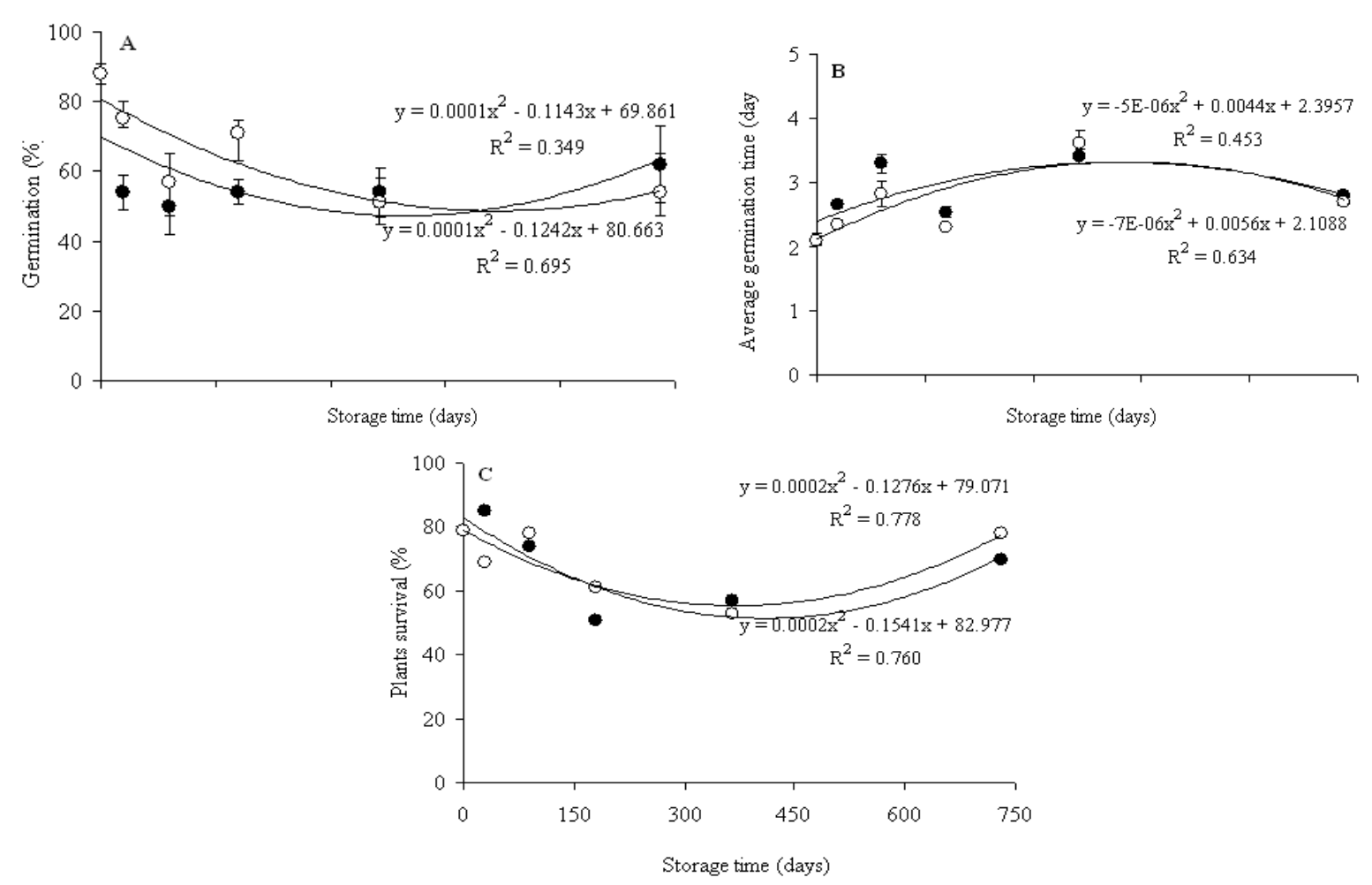

Figure 1 - Germination percentage (A), average germination time (B) and plants survival (C) of $C$.

echinata seeds after $0,30,90,180,365$ and 730 days of storage at $-18^{\circ} \mathrm{C}(\bullet)$ and at $196^{\circ} \mathrm{C}(\circ)$. The bars represent the standard error
The measures of plant growth from the seeds cryopreserved at 0,365 and 730 days of storage are presented in Table 1. Dry weight followed a descending order of leaf $>$ root $>$ stems, and did not vary according to the storage time or temperature. After 150 days of cultivation under values (less than 60\% survival) - coinciding with the summer season, when the average temperature was $29^{\circ} \mathrm{C}$ at the experiment site and high evaporation rates occurred.

The mean germination time ranged from 2.5 to 3.3 days, with no significant differences observed among the temperatures and the different storage periods tested (Fig. 1C). The average germination time of 3.3 day at 365 days was attributed to high levels of fungal contamination of the germinating seeds. The application Nystatin fungicide $(0.2 \%$ solution) during the germination tests at 730 days inhibited pathogen activity and reduced the average germination time to 2.5 days, with no significant differences observed between the different temperatures.

the greenhouse conditions, no significant differences were observed between the dry weight of the seedling structures, total dry weight of plants, hypocotyl length, or the numbers of leaves for the seeds stored for different times or at different temperatures. Internode length, however, 
was lower among seedlings produced by the seeds cryopreserved at $-196^{\circ} \mathrm{C}$ for 365 days (Table 1); this value increased again in the seeds stored for 730 days at that same temperature. The plants grown from the freshly harvested seeds had lower values for the numbers of nodes. The measures of growth reflected in the root:shoot ratio demonstrated greater biomass partitioning to the root system among the seedlings produced by the seeds frozen and stored for 365 days.

It is noteworthy that the lowest growth values as seen in Table 1 coincided with the last months of the summer.

Table 1 - Characteristics of early growth of $C$. echinata plants 150 days after the germination of seeds stored for 0 , 365 and 730 days at -18 and $-196^{\circ} \mathrm{C}$. $L D W=$ leaf dry weight; $S D W=$ stem dry weight; $R D W=$ root dry weight; TDM = total dry weight and $R: S=$ ratio of root to shoot dry weight. Means in columns followed by same letter do not differ by the Tukey test at $P<0.05(\mathrm{n}=10) . \pm$ represents the standard error.

\begin{tabular}{|c|c|c|c|c|c|c|c|c|c|}
\hline \multirow[t]{2}{*}{$\begin{array}{l}\text { Storage } \\
\text { time (days) }\end{array}$} & \multirow{2}{*}{$\begin{array}{l}\text { Storage } \\
\text { tempera } \\
\text { ture }\left({ }^{\circ} \mathrm{C}\right)\end{array}$} & $L D W$ & $S D W$ & $R D W$ & $T D W$ & Hypocotyl & $\begin{array}{l}\text { Internode } \\
\text { Length }\end{array}$ & Internode Leaves & \multirow[t]{2}{*}{$R: S$} \\
\hline & & \multicolumn{4}{|c|}{ mg DW } & \multicolumn{2}{|c|}{ cm } & $\mathbf{n}^{\circ}$ & \\
\hline Freshly & +025 & $496 \pm 20 \mathrm{~b}$ & $160 \pm 10$ & $300 \pm 10 \mathrm{a}$ & $960 \pm 030 \mathrm{a}$ & $3.6 \pm 0.3 \mathrm{a}$ & $4.1 \pm 0.1 \mathrm{ab}$ & $4.9 \pm 0.2$ a $4.7 \pm 0.4 \mathrm{a}$ & $0.46 \pm 0.03 \mathrm{a}$ \\
\hline & -018 & $390 \pm 20 \mathrm{ab}$ & $140 \pm 10$ & $380 \pm 40 a$ & $910 \pm 060$ a & $3.1 \pm 0.2 \mathrm{a}$ & $4.2 \pm 0.2 \mathrm{ab}$ & $7.2 \pm 0.3$ b $5.0 \pm 0.2 \mathrm{a}$ & $0.71 \pm 0.06 \mathrm{~b}$ \\
\hline 365 & -196 & $329 \pm 25$ a & $116 \pm 16$ & $266 \pm 30 \mathrm{a}$ & $711 \pm 065 \mathrm{a}$ & $2.7 \pm 0.3 \mathrm{a}$ & $3.6 \pm 0.2 \mathrm{a}$ & $7.2 \pm 0.3$ b $5.2 \pm 0.2 \mathrm{a}$ & $0.59 \pm 0.05 \mathrm{ab}$ \\
\hline 730 & -018 & $435 \pm 70 \mathrm{ab}$ & $140 \pm 20$ & $261 \pm 50 \mathrm{a}$ & $830 \pm 130 \mathrm{a}$ & $3.7 \pm 0.4 \mathrm{a}$ & $4.2 \pm 0.3 \mathrm{ab}$ & $6.0 \pm 0.2 \mathrm{~b} 4.8 \pm 0.3 \mathrm{a}$ & $0.45 \pm 0.04 \mathrm{a}$ \\
\hline 150 & -196 & $472 \pm 40 \mathrm{ab}$ & $175 \pm 20$ & $300 \pm 40 \mathrm{a}$ & $932 \pm 070 \mathrm{a}$ & $3.3 \pm 0.2 \mathrm{a}$ & $5.5 \pm 0.2 \mathrm{~b}$ & $6.1 \pm 0.2$ b $5.1 \pm 0.2 \mathrm{a}$ & $0.48 \pm 0.05 \mathrm{a}$ \\
\hline
\end{tabular}

The analysis of soluble carbohydrates in the cytoplasm of the $\mathrm{C}+\mathrm{E}$ and in the teguments of the seeds cryopreserved for 730 days are presented in Table 2. The $\mathrm{C}+\mathrm{E}$ were characterized by the higher levels of glucose, sucrose and fructose, with no differences being observed between the two cold temperatures tested; the carbohydrate concentrations ranged from 21 to $31 \mathrm{mg} \cdot \mathrm{g}^{-1}$ dry weight (DW). Mannitol and arabinose were also in higher concentrations in the $\mathrm{C}+\mathrm{E}$, but at very low concentrations, ranging from 0.09 to $1.3 \mathrm{mg} \cdot \mathrm{g}^{-1}$ DW. No differences were observed for the storage

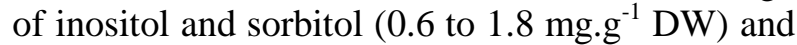
traces amounts of fucose (average $0.08 \mathrm{mg} \cdot \mathrm{g}^{-1}$ $\mathrm{DW})$ in the $\mathrm{C}+\mathrm{E}$ at different temperatures. Only galactose (average of $0.19 \mathrm{mg}^{-1} \mathrm{~g}^{-1} \mathrm{DW}$ ) was higher in the seed tegument as compared to the $\mathrm{C}+\mathrm{E}$.

Table 2 - Analysis of soluble carbohydrates concentrations in the cytoplasm of Cotyledons + Embryo $(\mathrm{C}+\mathrm{E})$ and teguments of $C$. echinata stored for 730 days at -18 and $-196^{\circ} \mathrm{C}$. Means in columns followed by same letter do not differ by the Tukey test at $P<0.05(\mathrm{n}=3)$. \pm represents the standard error.

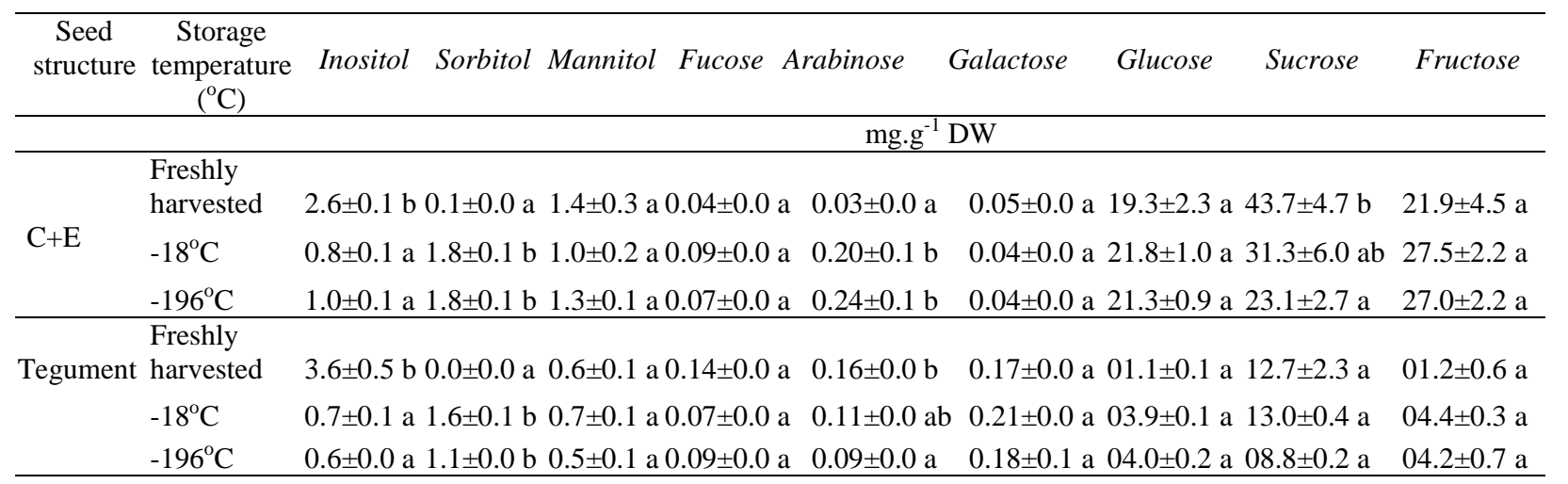

The concentrations of structural carbohydrates of the $\mathrm{C}+\mathrm{E}$ and seed teguments cryopreserved for 730 days are presented in Table 3. Concentrations of glucose in $\mathrm{C}+\mathrm{E}$ were high $\left(571 \mathrm{mg}^{-1}{ }^{-1} \mathrm{DW}\right)$, but with no differences observed between the two temperatures tested. The teguments were characterized by the higher levels of lignin (insoluble and soluble), with total lignin as the 
most abundant cell wall biomolecule $\left(553 \mathrm{mg} \cdot \mathrm{g}^{-1}\right.$ DW). The most representative carbohydrates in the tegument (in descending order) were glucose (141 $\left.\mathrm{mg} \cdot \mathrm{g}^{-1} \mathrm{DW}\right)$, arabinose $\left(63 \mathrm{mg} \cdot \mathrm{g}^{-1} \mathrm{DW}\right)$, xylose (22 $\left.\mathrm{mg} \cdot \mathrm{g}^{-1} \mathrm{DW}\right)$, galactose $\left(14 \mathrm{mg} \cdot \mathrm{g}^{-1} \mathrm{DW}\right)$, mannose (10.5 mg. $\left.\mathrm{g}^{-1} \mathrm{DW}\right)$ and fucose $\left(1.2 \mathrm{mg} \cdot \mathrm{g}^{-1} \mathrm{DW}\right)$. No significant differences were observed between the two temperatures tested for those carbohydrates. The only differences in the composition of soluble carbohydrates in the freshly harvested seeds as compared to the seeds stored at negative temperatures were the higher concentrations of sucrose, inositol, and sorbitol in both the $\mathrm{C}+\mathrm{E}$ and the teguments of the freshly-harvested seeds. No differences were found for the amount of structural carbohydrates in the tegument and the $\mathrm{C}+\mathrm{E}$ of seeds stored at low temperatures as compared to the freshly harvested seeds.

Table 3 - Analysis of the concentration of cell wall carbohydrates of embryo+cotyledons $(\mathrm{E}+\mathrm{C})$ and of the tegument of C. echinata seeds stored for 730 days at -18 and $-196^{\circ} \mathrm{C}$. Means in columns followed by same letter do not differ by the Tukey test at $P<0.05(\mathrm{n}=3)$. \pm represents the standard error.

\begin{tabular}{|c|c|c|c|c|c|c|c|c|c|c|}
\hline $\begin{array}{c}\text { Seed } \\
\text { structure }\end{array}$ & $\begin{array}{c}\text { Storage } \\
\text { Temperature } \\
\left({ }^{\circ} \mathrm{C}\right)\end{array}$ & Fucose & Arabinose & Galactose & Glucose & Xylose & Mannose & $\begin{array}{l}\text { Insoluble } \\
\text { lignin }\end{array}$ & $\begin{array}{c}\text { Soluble } \\
\text { lignin }\end{array}$ & $\begin{array}{c}\text { Total } \\
\text { Lignin }\end{array}$ \\
\hline & \multicolumn{10}{|c|}{ mg.g ${ }^{-1}$ DW } \\
\hline \multirow{3}{*}{$\mathrm{C}+\mathrm{E}$} & $\begin{array}{l}\text { Freshly } \\
\text { harvested }\end{array}$ & $0.7 \pm 0.0 \mathrm{a}$ & $35 \pm 0.4 \mathrm{a}$ & $10.7 \pm 0.2 \mathrm{~b}$ & $555 \pm 6.0 \mathrm{a}$ & $05.3 \pm 0.2 \mathrm{a}$ & $02.8 \pm 0.1 \mathrm{a}$ & $024 \pm 0.4 \mathrm{a}$ & $48 \pm 0.7 \mathrm{a}$ & $072 \pm 2.6 \mathrm{a}$ \\
\hline & $-18^{\circ} \mathrm{C}$ & $0.7 \pm 0.0 \mathrm{a}$ & $36 \pm 0.5 \mathrm{a}$ & $06.1 \pm 0.1 \mathrm{ab}$ & $561 \pm 3.5 \mathrm{a}$ & $05.0 \pm 0.2 \mathrm{a}$ & $03.2 \pm 0.1 \mathrm{a}$ & $019 \pm 0.2 \mathrm{a}$ & $47 \pm 0.8 \mathrm{a}$ & $067 \pm 1.1 \mathrm{a}$ \\
\hline & $-196^{\circ} \mathrm{C}$ & $0.6 \pm 0.0 \mathrm{a}$ & $36 \pm 0.7 \mathrm{a}$ & $05.6 \pm 0.1 \mathrm{a}$ & $583 \pm 4.3 \mathrm{a}$ & $05.2 \pm 0.0 \mathrm{a}$ & $03.3 \pm 0.1 \mathrm{a}$ & $019 \pm 0.2 \mathrm{a}$ & $49 \pm 0.8 \mathrm{a}$ & $069 \pm 1.0 \mathrm{a}$ \\
\hline \multirow[t]{3}{*}{ Tegument } & $\begin{array}{l}\text { Freshly } \\
\text { harvested }\end{array}$ & $1.1 \pm 0.0 \mathrm{a}$ & $53 \pm 0.5 \mathrm{a}$ & $12.2 \pm 0.3 \mathrm{a}$ & $213 \pm 5.3 \mathrm{a}$ & $26.4 \pm 0.6 \mathrm{a}$ & $12.4 \pm 0.4 \mathrm{a}$ & $450 \pm 6.2 \mathrm{a}$ & $55 \pm 0.7 \mathrm{a}$ & $507 \pm 5.3 \mathrm{a}$ \\
\hline & $-18^{\circ} \mathrm{C}$ & $1.2 \pm 0.0 \mathrm{a}$ & $64 \pm 1.0 \mathrm{a}$ & $14.5 \pm 1.2 \mathrm{a}$ & $146 \pm 0.2 \mathrm{a}$ & $20.5 \pm 0.4 \mathrm{a}$ & $10.1 \pm 0.1 \mathrm{a}$ & $495 \pm 3.1 \mathrm{a}$ & $56 \pm 0.9 \mathrm{a}$ & $552 \pm 3.2 \mathrm{a}$ \\
\hline & $-196^{\circ} \mathrm{C}$ & $1.2 \pm 0.0 \mathrm{a}$ & $63 \pm 2.3 \mathrm{a}$ & $13.8 \pm 0.8 \mathrm{a}$ & $138 \pm 3.0 \mathrm{a}$ & $23.8 \pm 0.3 \mathrm{a}$ & $11.2 \pm 0.4 \mathrm{a}$ & $501 \pm 2.8 \mathrm{a}$ & $57 \pm 0.9 \mathrm{a}$ & $559 \pm 3.1 \mathrm{a}$ \\
\hline
\end{tabular}

\section{DISCUSSION}

Seed longevity is influenced by the storage temperature and relative humidity. The reduction of these factors significantly increases the seed vigor and prolongs the longevity of the stored seeds (Sharma et al. 2007). The germination percentage of cryopreserved C. echinata seeds (at $-196^{\circ} \mathrm{C}$ ) decreased with increasing storage time (Fig. 1A). After 730 days of storage at low temperatures, the seed germination percentage was approximately $60 \%, 28 \%$ lower than the freshly harvested seeds. This would be expected if the seeds had been stored at positive temperatures, because energy-rich biomolecules tend to deteriorate under longer storage times (Sharma et al. 2005). A decline in the germination at low but positive temperatures was reported by Garcia et al. (2006), who observed a $19 \%$ reduction in the germination of $C$. echinata seeds in relation to freshly harvested seeds after 18 months of storage at $6^{\circ} \mathrm{C}$.

The reduction in the germination among the cryopreserved seeds as compared to those that were not cryopreserved (Fig. 1A) could be due to mechanical and physiological changes caused by the temperature stress during the cryopreservation process. Increased cracking of the endocarp of seeds has been observed during the freezing and thawing of cryopreserved seeds (Salomão 2001). Upon thawing, the seed teguments of $C$. echinata proved to be dry and brittle in the present study (results not shown). However, the brownish color and purplish areas of the freshly harvested seeds were maintained at the temperatures tested. Another aspect that must be carefully evaluated would be the moisture content of seeds to be cryopreserved (Dickie 1995, Potts and Lumpkin 1997), as residual moisture contents below $8.7 \%$ appeared to result in better seed germination.

While the seeds stored at $-18^{\circ} \mathrm{C}$ did not receive special processing before freezing (as was undertaken by the seeds stored at $-196^{\circ} \mathrm{C}$ ), the results were satisfactory and similar at both the temperatures. Similar results were reported for the orthodox species of the genus Brassica (PérezGarcia et al. 1996), Bratonia (Popova et al. 2003), and Halimium and Helianthemum (Pérez-Garcia and González-Benito 2008) cryopreserved in liquid nitrogen. Germination percentages could 
possibly have been improved if these authors had tested different methods of freezing and thawing. According to Molina et al. (2006), onion seeds subjected to fast thawing had higher germination rates than the seeds subjected to slow thawing. Rapid thawing prevents the formation of ice crystals within the seed, thus avoiding the cell membrane disruption and the loss of cellular compartmentalization (Salomão 2002).

Although the water content of the $C$. echinata seeds had been reduced to critical levels $(8.7 \%)$ tolerated by this species (Barbedo 2002, Hellmann et al. 2006) and recommended for cryopreservation, the presente results still pointed to possible cell damage. One method of preventing the formation of ice crystals is to rapidly thaw them in a water bath or by fast microwave heating (Molina et al. 2006). The melt water would not have enough time to recrystallize under these conditions and would not threaten cellular integrity.

The decrease in germination percentages of the cryopreserved $C$. echinata seeds in relation to the freshly harvested seeds did not extend to their germination time (Fig. 1B) or the percentage survival of the seedlings (Fig. 1C). Average germination time was higher at both the cryopreservation temperatures after 90 and 365 days when higher proliferation of pathogens was observed. Fungal contamination is one of the most serious problems encountered in the germination tests, especially when these experiments are performed in the incubators, which present ideal conditions for the proliferation microorganisms (Calistru et al. 2000). To minimize this problem, the fungicide Nystatin $(0.2 \%)$ was used in the final germination test (730 days of storage), thus the reducing contamination and consequently decreasing the seed germination time. It should be noted that the seed tegument harbored a wide diversity of microorganisms (especially among the tropical seeds) (Khurana and Singh 2001), and $C$. echinata seeds devoid of any tegument germinted very well and produced healthy seedlings under aseptic in vitro conditions (pers. comm. Werner 2009).

The low survival rates of the plants grown from the seeds subjected to freezing temperatures for 180 and 365 , as seen in the present study, could have been influenced by the high temperatures and solar radiation levels, and high evaporation rates of soil water during the hot summer months, in spite of daily watering in the greenhouse. This sensitivity of $C$. echinata seedlings to water stress is enhanced by the ecological characteristics of this intermediate/initial successional species that is sensitive to direct solar radiation associated with a higher temperature (Mengarda et al. 2009).

Storage temperatures did not affect plant vigor (as indicated by seedling survival percentages) (Fig. 1C), and no morphological or physiological changes were observed in the analysis of growth stages of the plants grown from the cryopreserved seeds (Table 1). Similar results were reported by (Popova et al. 2003) with protocorms of Bratonia (a hybrid orchid) after 639 days of in vitro growth of the cryopreserved seeds. The short internode lengths of Brazilwood plants produced from seeds stored for 365 days at $-196^{\circ} \mathrm{C}$, the lower numbers of internodes of seedlings grown from the freshly harvested seeds, and the low root:shoot ratio of plants produced by freshly-harvested seeds stored for 730 days, regardless of the method of cryopreservation, could have been a reflection of unfavorable environmental conditions during the hot summer months.

The temperatures and storage times of $C$. echinata seeds did not affect the plant vigor as indicated by the high percentage of plant survival and normal morphological characteristics of seedlings produced from cryopreserved seeds. Therefore, it was conclude that the negative temperatures tested and the techniques of freezing and thawing of the seeds cryopreserved in liquid nitrogen had no cumulative negative effects on plant growth.

No differences were observed for the concentrations of soluble carbohydrates in the cytoplasm (Table 1) or structural carbohydrates (Table 2) of the $\mathrm{C}+\mathrm{E}$ or teguments between the two temperatures tested, except for the distribution of these molecules between the seed coats and cotyledons. Soluble carbohydrate levels in the cytoplasm were higher in the $\mathrm{C}+\mathrm{E}$ than in the teguments: arabinose $(0.02 \%)$, mannitol $(0.11 \%$ DW), glucose (2\% DW), sucrose (2.7\% DW) and fructose $(2.7 \% \mathrm{DW})$. Only galactose $(0.02 \%)$ was shown to have higher concentrations in the seed teguments as compared to the $\mathrm{C}+\mathrm{E}$. No differences were observed between the inositol $(0.08 \%$ DW) and sorbitol $(0.08 \%$ DW) concentrations or the trace amounts of fucose found in the different seed structures after exposure to different storage temperatures. Similarly, the quantities of soluble carbohydrates observed after storage under both low temperatures were similar to those of freshly harvested seeds. Higher values of inositol and 
traces of sorbitol, however, were detected in the $\mathrm{C}+\mathrm{E}$ and the teguments of the freshly harvested seeds, with trace amounts of arabinose and higher concentrations of sucrose in the $\mathrm{C}+\mathrm{E}$. These variations suggested that even at negatives temperatures, the $8.7 \%$ moisture content of Brazilwood seeds was not enough to completely paralyze the cell metabolism. As inositol and sucrose are among the carbohydrates involved in protecting the biological membranes (Dumet et al. 1994) of the seeds with recalcitrant characteristics, such as C. echinata (Borges et al. 2006), the catabolism of these sugars may occur even at freezing temperatures and may contribute to the reduction in the germination after 730 days of storage under even extremely cold conditions (Fig. 1A).

Regarding of the cell wall components (Table 2), the tegument had a high lignin content, including the monosaccharides fucose, arabinose, galactose, xylose and mannose. The total lignin content was high $(55 \% \mathrm{DW})$, followed by glucose (14\% DW), arabinose $(6 \% \mathrm{DW})$, xylose $(2 \% \mathrm{DW})$, mannose $(1 \%$ DW $)$ and fucose $(0.1 \%$ DW). It was noteworthy that the composition of structural carbohydrates in the $\mathrm{C}+\mathrm{E}$ and in the tegument of seeds stored at the two negative temperatures did not differ from the composition of the freshly harvested seeds. The high concentration of glucose in the cell wall of the $\mathrm{C}+\mathrm{E}(57 \% \mathrm{DW})$ suggested an important role for the cell-wall polysaccharides in the mobilization of carbohydrates during the germination of $C$. echinata, although other cell wall carbohydrates (with lower concentrations in the cotyledons) also played significant roles. The concentrations of fucose, arabinose and galactose represented $50 \%$ of the concentration of all of the carbohydrates encountered in the seed teguments, while xylose and mannose accounted for $40 \%$, and total lignin for only $7 \%$ of the dry weight.

The different sub-zero storage temperatures tested did not alter the seed germination or plant morphology, and there were no significant changes in the composition of the structural and nonstructural carbohydrates of $C$. echinata seeds. These results, therefore, confirmed the efficiency of cryopreservation techniques in maintaining the seed vigor during the medium and long-term storage. Additionally, the conservation of the seeds at negatives temperatures without the need for using liquid nitrogen is highly advantageous in terms of reducing the costs while still providing the satisfactory preservation. The results presented here demonstrated the need to evaluate other freezing and thawing techniques and to determine the seed tolerance to dehydration before freezing (Potts and Lumpkin 1997, Salomão 2002 Molina et al. 2006) in order to assure the germination percentages similar to those of freshly harvested seeds.

\section{ACKNOWLEDGEMENTS}

The authors would like to thank Fundação Biodiversitas, Fundo de Apoio à Ciência e Tecnologia da Prefeitura Municipal de Vitória (FACITEC), and e Fundação de Apoio à Ciência e Tecnologia do Espírito Santo (FAPES) for their financial support. We also thank Petrobrás for the grant awarded

\section{REFERENCES}

ASTM E 1758-01. Standard Practice for Preparation of Biomass for Compositional Analysis. American Society for Testing and Materials. 2001; USA.

ASTM E 1690-01. Standard Practice for Determination of Ethanol Extractives in Biomass. American Society for Testing and Materials. 2001; USA.

ASTM E 1757-01. Standard Test Method for Determination of Carbohydrates in Biomass by High Performance Liquid Chromatography. American Society for Testing and Materials. 2001; USA.

ASTM E 1721-01. Standard Test Method for Acid Insoluble residue in Biomass. American Society for Testing and Materials. 2001; USA.

Barbedo CJ, Bilia DAC, Figueiredo-Ribeiro RCF. Tolerância à dessecação e armazenamento de sementes de Caesalpinia echinata Lam. (pau-brasil), espécie da Mata Atlântica. Rev. bras. Bot. 2002; 25(4): 431-439.

Borges IF, Barbedo CJ, Richter AA, FigueiredoRibeiro RCL. Variations in sugars and cyclitols during development and maturation of seeds of brazilwood (Caesalpinia echinata Lam., Leguminosae). Braz. J. Plant Physiol. 2006; 18(4) 475-482.

Calistru C, McLean M, Pammenter NW, Berjak P. The effects of mycofloral infection on the viability and ultrastructure of wet-stored recalcitrant seeds of Avicennia marina (Forsk.) Vierh. Seed Sci. Res. 2000; 10: 341-353.

Carneiro CS, Cal-Vidal J. Ice crystal structuring as affected by amphiphilic substances. J. Scanning Microsc. 1998; 20(3): 244-246. 
Carneiro CS, Cal-Vidal J. Estruturação de cristais de gelo em soluções aquosas contendo solutos diversos. Pesq. agropec. brasil. 2000; 35(2): 423-432.

Dickie JB, Smith RD. Observations on the survival of seeds of Agathis spp. stored at low moisture contents and temperatures. Seed Sci. Res. 1995, 5: 5-14.

Dumet D, Engelmann F, Chabrillange N, Dussert S, Duval Y. Effect of various sugars and polyols on the tolerance to desiccation and freezing of oil palm polyembryonic cultures. Seed Sci. Res. 1994; 4: 307313.

Garcia IS, Souza A, Barbedo CJ, Dietrich SM, Figueiredo-Ribeiro RCL. Changes in soluble carbohydrates during storage of Caesalpinia echinata LAM. (Brazilwood) seeds, an endangered leguminous tree from the Brazilian Atlantic Forest. Braz. J. Biol. 2006; 66: 739-745.

Hellmann ME, Mello JIO, Figueiredo-Ribeiro RCL, Barbedo CJ. Tolerância ao congelamento de sementes de pau-brasil (Caesalpinia echinata Lam.) influenciada pelo teor de água inicial. Rev. bras. Bot. 2006; 29(1): 93-101.

Hellmann ME, Mello JIO, Barbedo CJ, FigueiredoRibeiro RCL. Variações dos carboidratos de reserva de sementes de Caesalpinia echinata (pau-brasil) armazenadas sob diferentes temperaturas. Hoehnea, 2008; 35(2): 255-264.

Khurana E, Singh JS. Ecology of seed and seedling growth for conservation and restoration of tropical dry forest: a review. Environ. Conserv. 2001; 28(1): 93-52.

Mengarda HG, Souza RLF, Campostrini E, Reis FO, Cuzzuol GRF. The light as indicator of the ecological succession of the brazilwood (Caesalpinia echinata Lam.). Braz. J. Plant Physiol. 2009; 21: 55-63.

Molina TF, Tillmann MAA, Dode LB, Viégas J. Criopreservação em sementes de cebola. Rev. bras. sementes. 2006; 28(3): 72-81.

Nkang A. Carbohydrate composition during seed development and germination in two sub-tropical tree species (Erythrina caffra and Guilfoylia monostylis). J. Plant Physiol. 2002; 159: 473-483.
Pérez-Garcia F, Gonzalez-Benito ME, Pérez C, GómezCampo C. Effect of cryopreservation on Brassica seeds germination. Acta Hort. 1996; 407: 255-260.

Pérez-Garcia F, González-Benito EM. Seed cryopreservation of Halimium and Helianthemun species. CryoLetters, 2008; 29(40): 271-276

Piotrowicz-Cieslak A. Composition of seed soluble carbohydrates and ultrastructural diversity of testa in Lupins from the Mediterranean region. Acta Soc. Bot. Pol. 2005; 72(4): 281-286.

Popova EV, Nikishina TV, Kolomeitseva GL, Popov AS. (2003), The effect of seed cryopreservation on the development of protocorms by the hybrid Orchid Bratonia. Russ. J. Plant Physl. 2003; 50(5): 672-677.

Potts SE, Lumpkin TA. Cryopreservation of Wasabia spp. seeds. CryoLetters, 1997; 18: 185-190.

Salomão AN. Avaliação da Tolerância de Sementes de Joá (Zizyphus joazeiro) à exposição ao Nitrogênio Líquido. Boletim de Pesquisa e Desenvolvimento. 2001; 16p.

Salomão AN. Tropical seed species' responses to liquid nitrogen exposure. Braz. J. Plant Physiol. 2002; 14(2): 133-138.

Sharma S, Virdi P, Gambhir S, Munshi SK. Changes in soluble sugar content and antioxidant enzymes in soybean seeds stored under different storage conditions. Indian J. Agr. Biochm. 2005; 18: 9-12.

Sharma S, Gambhir S, Munshi K. Changes in lipid and carbohydrate composition of germinating soybean seeds under different storage conditions. Asian $J$. Plant Sci. 2007; 6(3): 502-507.

Received: March 10, 2011; Revised: August 16, 2011; Accepted: March 12, 2012. 


\section{PAGINA \\ EM \\ BRANCO}

